\title{
Resolving natal tags using otolith geochemistry in an estuarine fish, rainbow smelt Osmerus mordax
}

\author{
Ian R. Bradbury ${ }^{1,4}$, Claudio DiBacco ${ }^{2}$, Simon R. Thorrold ${ }^{3}$, Paul V. R. Snelgrove ${ }^{4}$, \\ Steven E. Campana ${ }^{2}$
}

${ }^{1}$ Fisheries and Oceans Canada, Science Branch, 80 East White Hills Road, PO Box 5667, St. John's, Newfoundland and Labrador A1C 5X1, Canada

${ }^{2}$ Fisheries and Oceans Canada, Bedford Institute of Oceanography, PO Box 1006, Dartmouth, Nova Scotia B2Y 4A2, Canada

${ }^{3}$ Biology Department, MS \#50, Woods Hole Oceanographic Institution, Woods Hole, Massachusetts 02543, USA

${ }^{4}$ Ocean Sciences Centre and Biology Department, Memorial University of Newfoundland, PO Box 4200, St. John's, Newfoundland and Labrador A1C 5S7, Canada

\begin{abstract}
Dispersal and connectivity are central to stability and persistence in natural populations. The use of otolith composition as geo-referenced tags may provide unparalleled resolution of spatial movements in marine and anadromous fish, although these geochemical signatures remain largely undescribed and the factors influencing otolith composition poorly understood. We examined spatial variation in the otolith geochemistry of juvenile rainbow smelt Osmerus mordax using laser ablation inductively coupled plasma mass spectrometry (LA-ICP-MS) and isotope ratio monitoring mass spectrometry to evaluate its potential as a natural tag to resolve fine-scale geographic patterns and dispersal of estuarine early life history stages. Otolith element ratios (Mg:Ca, Mn:Ca, Sr:Ca, Ba:Ca) and isotope ratios $\left(\delta^{13} \mathrm{C}, \delta^{18} \mathrm{O},{ }^{87: 86} \mathrm{Sr}\right)$ varied significantly among locations $(\mathrm{n}=9)$ and provided $83 \%$ crossvalidated accuracy using a quadratic discriminant function analysis. Assignments based only on the 3 isotope variables resulted in the highest rates of correct assignment ( $87 \%)$, largely driven by a significant increase $(\sim 11 \%)$ in correct assignments at nearby locations $(<20 \mathrm{~km}$ distant). Five of the 7 elements examined were significantly correlated with each other, consistent with a common response to estuarine differences. We also observed a significant effect of habitat on assignment success, in that sites with partially restricted marine access (i.e. sand bars) assigned correctly at significantly higher rates. This study demonstrates that geochemical otolith signatures are intimately linked to estuarine structure, which in turn directly influences assignment power. It also demonstrates that assignment over fine spatial scales $(<20 \mathrm{~km})$ can be maximized by the examination of isotope signatures and sampling of specific habitat types.
\end{abstract}

KEY WORDS: Otolith chemistry $\cdot$ Rainbow smelt $\cdot$ Connectivity $\cdot$ Population structure $\cdot$ Elemental fingerprint

Resale or republication not permitted without written consent of the publisher

\section{INTRODUCTION}

Geographic translocation (i.e. dispersal) from birth to reproduction is a principal determinant of population structure, stability, and persistence (Hastings \& Botsford 2006, Campbell Grant et al. 2010). Connectivity in marine species is often the culmination of passive and active processes during both the larval and adult stages (Bradbury \& Snelgrove 2001, Pineda et al. 2007,
Botsford et al. 2009). The measurement of connectivity in species where lifetime dispersal may span large geographic distances and multiple life history stages has therefore proven challenging. Despite recent progress in measuring dispersal (e.g. Thorrold et al. 2001, Jones et al. 2005), the few marine and estuarine species for which estimates of dispersal exist are insufficient to infer general trends (Bradbury et al. 2008a). Nonetheless, studies increasingly suggest significant 
interspecific and intraspecific variability in dispersal, and contradict previous assumptions of widespread, long-distance larval transport among marine taxa (Levin 2006). Clearly, a better understanding of connectivity and dispersal pathways in marine and estuarine organisms is necessary for improved sustainability and conservation of marine species and communities (Sale et al. 2005, Almany et al. 2009).

Several approaches to measuring movement patterns in marine and estuarine species exist (see reviews in Cadrin et al. 2005, DiBacco et al. 2006, Elsdon et al. 2008). Indirect molecular genetic approaches rely on population-scale differences in allele frequency and on models of population structure to estimate rates of average exchange among populations (e.g. Bradbury \& Bentzen 2007). However, the application of population allele frequency estimates of connectivity to contemporary management remains tenuous, given the possibility of alternate demographic influences (e.g. bottlenecks and non-equilibrium conditions) and the large temporal scales over which they integrate. Direct measures of dispersal, by contrast, often rely on genetic (e.g. Jones et al. 2005, SaenzAgudelo et al. 2009) or geochemical (e.g. Campana et al. 1999, Thorrold et al. 2001, Elsdon et al. 2008) tags. Over fine spatial scales of $\mathrm{km}$ to hundreds of $\mathrm{km}$, movement is likely most frequent, and non-genetic tags such as otolith composition are often most informative (e.g. Thorrold et al. 2001, Fodrie \& Herzka 2008). The utility of otolith composition as a geographic tag stems from the fact that otoliths are largely metabolically inert, are accreted continuously with age, and can reflect ambient hydrography (Campana \& Thorrold 2001, Elsdon et al. 2008). Where differences in local hydrography (viz. temperature, salinity) exist, multi-chemical signatures of otolith composition may act as a natal tag, allowing assignment of individuals to discrete natal habitats (Elsdon et al. 2008, Fodrie \& Levin 2008).

Rainbow smelt Osmerus mordax (Mitchill, 1814) is a small pelagic fish found in coastal and freshwater systems throughout northeastern North America (Nellbring 1989). Anadromous smelt spawn near the head of the tide in coastal rivers and streams during the spring, with peak spawning timing varying among sites from late April to June. Eggs hatch over a 1 mo period and larvae develop in downstream estuaries during the summer and early autumn (e.g. Ouellet \& Dodson 1985, Bradbury et al. 2004). Smelt typically mature at 2 to $3 \mathrm{yr}$ of age and may live from 4 to $5 \mathrm{yr}$ (McKenzie 1964). Prior work suggests significant behavioural contributions to early life-history patterns in the form of synchronized hatch (Bradbury et al. 2004) and diel vertical migration (Laprise \& Dodson 1989, Bradbury et al. 2006), which may result in larval retention within single estuaries (Bradbury et al. 2006). Straying among estuaries during both early life and adult stages has nonetheless been reported even among locations displaying clear evidence of genetic isolation (Bradbury et al. 2008b,c). The persistence of isolation in the face of dispersal may reflect local adaptation and strong selection against straying. Given that smelt populations inhabit a diverse array of habitats ranging from open estuaries, to estuaries with obstructions (such as sand bars) that partially restrict sea access, to coastal ponds where sea access is virtually absent, there is considerable potential for distinct natal or nursery area signatures that may permit further insight into the contribution of various ecological and evolutionary forces influencing connectivity.

The overall goal of this work, carried out at several sites in southeastern Newfoundland, was to evaluate the use of otolith geochemistry as a natural tag for natal habitat in rainbow smelt and to investigate the factors influencing assignment success. Our objectives were: (1) to examine elemental and isotopic signatures (as well as associations among elements and isotopes) at the core of juvenile ( 3 mo old) otoliths; (2) to evaluate the potential for assignment of juvenile individuals to habitats of origin based on these geochemical signatures, and to identify the most informative suite of geochemical variables for accurate, fine-scale spatial assignment; and (3) to evaluate the influence that distinct habitat features may have upon otolith composition and assignment success, specifically addressing the question of whether estuaries with limited exchange with the ocean provide greater classification accuracy. The aim was both to describe the geochemical signatures for natal assignment in rainbow smelt and to discover which tools and habitats are most promising for fine-scale assignment of individuals in estuarine and marine species.

\section{MATERIALS AND METHODS}

Sample collection. Sampling locations were spread over $500 \mathrm{~km}$ of coastline in southeastern Newfoundland, Canada (Fig. 1). We sampled 9 known smelt spawning locations identified from previous coastal surveys (e.g. Methven et al. 1998) by deploying a $25 \mathrm{~m}$ seine from a small boat in shallow water (usually $<10 \mathrm{~m}$ deep) which 2 people then hauled ashore. Each haul swept the bottom $2 \mathrm{~m}$ of the water column over an area of $\sim 880 \mathrm{~m}^{2}$ (16 $\mathrm{m}$ along the shore by $55 \mathrm{~m}$ from offshore to the beach). The seine retained fishes of $>20 \mathrm{~mm}$ total length (TL) within the codend. Multiple tows were completed at each site in adjacent but non-overlapping locations in rapid succession until adequate numbers of fish ( $\mathrm{n}=50$ juvenile smelt per site) were 


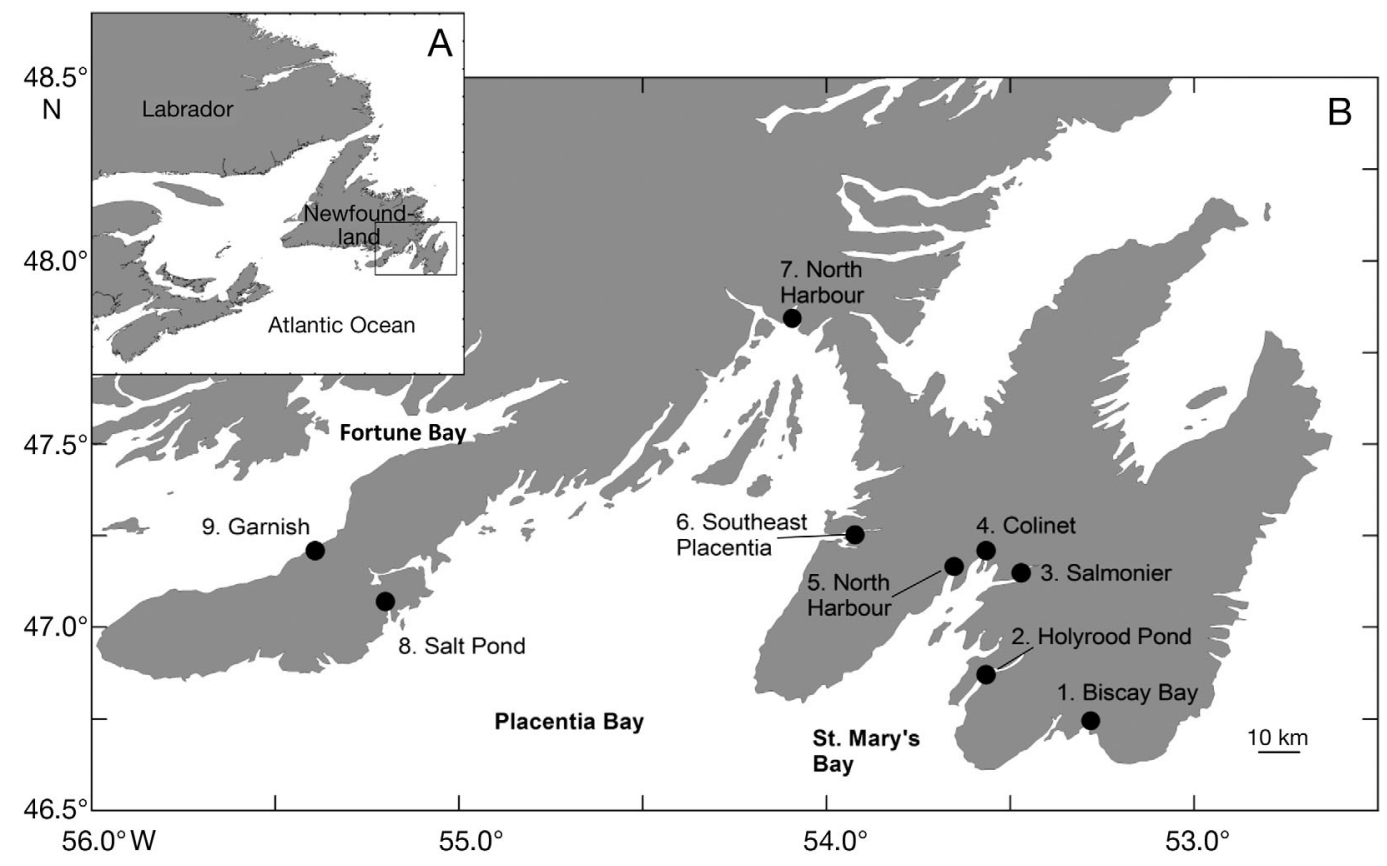

Fig. 1. Osmerus mordax. (a) Location of Newfoundland with respect to eastern Canada. Study area outlined at lower right. (b) Study area showing the 9 sampling locations

collected, measured for TL, and preserved in $95 \%$ ethanol (Hedges et al. 2004). All sites were sampled between October and November 2004.

Otolith preparation and geochemical analysis. We selected individuals measuring $\leq 80 \mathrm{~mm}$ TL for otolith extraction, assuming that those individuals had been recruited that year (McKenzie 1964; Table 1). The number of individuals for the elemental and $\mathrm{Sr}$ isotope $\left({ }^{87: 86} \mathrm{Sr}\right)$ analysis ranged from 41 at Garnish to 20 at North Harbour (Placentia Bay); for all $\delta^{13} \mathrm{C}$ and $\delta^{18} \mathrm{O}$ analysis, sample sizes were 20 ind. per location (Table 1). Sampled individuals varied in average fork length from $46.1 \mathrm{~mm}$ at Biscay Bay to $61.3 \mathrm{~mm}$ at Holyrood Pond. Both sagittal otoliths were removed, cleaned with ultrapure water, air-dried, and stored in acidwashed glass vials until they were mounted on glass microscope slides and polished to the core using fine lapping film. Mounted otoliths were then cleaned again with a nylon brush, triple-rinsed in ultrapure water, and sonified for 2 min before being airdried in a laminar-flow hood and transferred to clean Petri dishes. We measured elemental composition of the core of 1 of the 2 otoliths using laser ablation inductively coupled plasma mass spectrometry (LA-ICP-MS), which coupled an ArF excimer $193 \mathrm{~nm}$ laser to a Thermo Finnigan Element 2
ICP-MS for detection and measurement at the Woods Hole Oceanographic Institution Plasma Mass Spectrometry facility. We chose to quantify isotopes of 5 elements $\left({ }^{25} \mathrm{Mg},{ }^{43} \mathrm{Ca},{ }^{55} \mathrm{Mn},{ }^{88} \mathrm{Sr},{ }^{138} \mathrm{Ba}\right)$, because they are commonly used in discrimination and assignment studies (Elsdon et al. 2008), preliminary analysis had indicated that these elements were consistently higher than background environmental levels. Assays consisted of a single $80 \mu \mathrm{m}$ spot with a repetition rate of $5 \mathrm{~Hz}$ and dwell time of $60 \mathrm{~s}$. A certified reference material (CRM) consisting of powdered otoliths (Yoshinaga et al. 2000), dissolved in $2 \% \mathrm{HNO}_{3}$ and diluted to a Ca concentration of $40 \mathrm{\mu g} \mathrm{g}^{-1}$, was used to correct

Table 1. Sample locations, average total length (TL) and sample sizes (N) for geochemical analysis of rainbow smelt otoliths, coastal Newfoundland. See also Fig. 1. Location codes - SMB: St. Mary's Bay; PB: Placentia Bay; FB: Fortune Bay; B: barred estuary; O: open estuary

\begin{tabular}{|c|c|c|c|c|c|}
\hline ID & $\begin{array}{l}- \text { Location } \\
\text { Name (estuary type) }\end{array}$ & Code & $\begin{array}{c}\mathrm{TL} \\
(\mathrm{mm})\end{array}$ & $\begin{array}{l}\text { N element } \\
\text { and }{ }^{87 / 86} \mathrm{Sr}\end{array}$ & $\begin{array}{c}\mathrm{N} \delta^{18} \mathrm{O} / \\
\delta^{13} \mathrm{C}\end{array}$ \\
\hline 1 & Biscay Bay, SMB (B) & BIS & 46.1 & 34 & 20 \\
\hline 2 & Holyrood Pond, SMB (B) & HRP & 61.3 & 30 & 20 \\
\hline 3 & Salmonier, SMB (O) & SAL & 48.6 & 37 & 20 \\
\hline 4 & Colinet, SMB (O) & $\mathrm{COL}$ & 53.9 & 34 & 20 \\
\hline 5 & North Harbour, SMB (O) & NSM & 53.1 & 31 & 20 \\
\hline 6 & Southeast Placentia, PB (B) & SEP & 55.7 & 33 & 20 \\
\hline 7 & North Harbour, PB (O) & NPB & 47.2 & 20 & 20 \\
\hline 8 & Salt Pond, PB (B) & SLT & 53.0 & 31 & 20 \\
\hline \multirow[t]{2}{*}{9} & Garnish, FB (B) & GAR & 62.8 & 41 & 20 \\
\hline & Total & & & 291 & 180 \\
\hline
\end{tabular}


for instrument bias and drift, following Thorrold \& Swearer (2009). We estimated external precision periodically throughout the laser analyses by assaying a second otolith CRM (Sturgeon et al. 2005), also dissolved in $\mathrm{HNO}_{3}$ and diluted to a Ca concentration of $40 \mu \mathrm{g} \mathrm{g}^{-1}$. We estimated limits of detection (LOD) as $3 \times$ the mean intensities of the blanks $\left(2 \% \mathrm{HNO}_{3}\right)$, run every 10 assays, which produced LOD values of $0.28 \%$ for $\mathrm{Ca}, 1.3 \%$ for $\mathrm{Mg}, 2.16 \%$ for $\mathrm{Mn}, 0.05 \%$ for $\mathrm{Sr}$, and $0.97 \%$ for Ba. Estimates of precision based on the relative SD values of the second CRM were $4.2 \%$ for $\mathrm{Mg}$, $21.4 \%$ for $\mathrm{Mn}, 0.35 \%$ for $\mathrm{Sr}$, and $0.87 \%$ for Ba.

Sr isotope ratio $\left({ }^{87: 86} \mathrm{Sr}\right)$ was analyzed on the second otolith using a Thermo Finnigan Neptune MC-ICP-MS at the Woods Hole Oceanographic Institution Plasma Mass Spectrometry facility. We sampled an $80 \mu \mathrm{m}$ spot on the core of the second otolith with a $105 \mathrm{~s}$ dwell time, and measured ${ }^{82} \mathrm{Kr},{ }^{83} \mathrm{Kr},{ }^{84} \mathrm{Sr},{ }^{85} \mathrm{Rb},{ }^{86} \mathrm{Sr},{ }^{87} \mathrm{Sr}$, and ${ }^{88} \mathrm{Sr}$ during each ablation. Although multiple potential sources of interference on Sr isotopes exist in carbonates, previous work identified only $\mathrm{Rb}$ and $\mathrm{Kr}$ as significant challenges to estimation of ${ }^{87: 86} \mathrm{Sr}$ for this instrument (Barnett-Johnson et al. 2005, Jackson \& Hart 2006). We therefore used a mass-bias correction with ${ }^{85} \mathrm{Rb}$ to remove the influence of ${ }^{87} \mathrm{Rb}$ on ${ }^{87} \mathrm{Sr}$. To correct for $\mathrm{Kr}$ interference on $\delta^{86} \mathrm{Sr}$ we followed Jackson \& Hart (2006), as outlined in Walther et al. (2008). Finally, all data were normalized to the standard reference material (SRM) 987. Daily sampling of National Institute of Standards and Technology SRM 987 ( $\mathrm{N}=35)$ and the otolith CRM $(\mathrm{N}=52)$ produced means $\pm \mathrm{SD}$ of $0.71027 \pm 0.00003$ and $0.70917 \pm 0.00003$, respectively, which are comparable to the global marine ${ }^{87: 86} \mathrm{Sr}$ value of 0.70917 (Barnett-Johnson et al. 2005) and the certified SRM 987 value of 0.71024 .

Otolith $\delta^{13} \mathrm{C}$ and $\delta^{18} \mathrm{O}$ signatures in one of the sagittal otoliths of each individual were also examined by milling otoliths with a MicroMill sampler (New Wave Research) or a handheld dental drill under a stereomicroscope until we obtained 50 to $200 \mu \mathrm{g}$ of the remaining material around the core. Otoliths were decontaminated again prior to milling as described above. Analysis was conducted at the Bloomsbury Environmental Isotope facility at University College London on a ThermoFinnigan DeltaPLUS XP stable isotope mass spectrometer attached to a ThermoScientific Gas Bench II device. Standards and samples (>100 $\mu \mathrm{g})$ were loaded into glass vials, methanol-rinsed and kept overnight in a $70^{\circ} \mathrm{C}$ oven. For analysis, each vial was acidified by manually injecting $100 \% \mathrm{H}_{3} \mathrm{PO}_{4}(0.1 \mathrm{ml})$ via the screw-cap septum. Precision of all internal (BDH, IAEA, IFC) and external (NBS19) standards is \pm 0.03 for $\delta^{13} \mathrm{C}$ and \pm 0.08 for $\delta^{18} \mathrm{O}$. All values are reported in the Vienna Pee Dee Bee (VPDB) notation, relative to NBS19.
Statistical analysis. Data for each elemental and isotope ratio were visually assessed for normality and logtransformed as necessary. We tested for geochemical differences among locations using both univariate ANOVA for each variable separately, and a multivariate analysis of variance (MANOVA) that simultaneously compared all ratios. For MANOVA we chose Pillai's trace as the test statistic because it is appropriate for small unequal samples. MANOVA was conducted at the scale of individual sample locations (Fig. 1), with sample locations 2, 3, 5, and 7 pooled based on the distribution of DFA assignments (see 'Results - Otolith geochemistry' below); and sample locations pooled within disjunct bays (Fig. 1). To identify consistent significant differences along locations and variables, we compared each location and chemical combination against pooled remaining samples or chemicals using ANOVA. Each population was compared with the total dataset, excluding itself. We evaluated correlations among chemical signatures using Pearson's correlation coefficient, and graphical analysis using hierarchical clustering of the correlation coefficient.

We examined the utility of geochemical signatures for spatial assignment at multiple geographic scales using a quadratic discriminant function analysis (QDFA) with cross-validation using the elemental and isotope data separately and for all variables combined. We chose QDFA over linear discriminant function analysis because it is free of assumptions regarding homogeneity of covariance matrices. Levels of correct assignment were compared among open and barred estuaries using ANOVA. Open and barred estuaries refer to estuaries with open access to the Atlantic Ocean or with a partial (usually $>80 \%$ ) obstruction.

\section{RESULTS}

\section{Otolith geochemistry}

Otolith geochemistry varied significantly among sample locations. Univariate analysis (ANOVA, Table 2, Figs. 2 \& 3) showed significant differences among sample locations for all measured element and isotope ratios (Table 2). The $\mathrm{r}^{2}$ values from the ANOVA exceeded $50 \%$ for 5 variables (see Table 2), of which $\delta^{13} \mathrm{C}$ was the highest at $94.5 \%$. Of the sampled locations, the Garnish sample deviated most from the pooled remaining samples with significant differences in all 7 variables examined (Table S1 in the supplement at www-int-res.com/articles/suppl/m433p195_ supp.pdf), displaying the lowest values for $\mathrm{Sr}: \mathrm{Ca}$ and all isotopes and the highest $\mathrm{Ba}$ :Ca values. Of the elements or isotopes examined here, $\delta^{13} \mathrm{C}, \delta^{18} \mathrm{O}$, and $\mathrm{Mg}$ :Ca differed significantly at the largest number $(\geq 6)$ 
Table 2. Univariate ANOVA examining element and isotopic ratios in juvenile rainbow smelt otolith cores at sample locations throughout southeastern Newfoundland (see Fig. 1). Combined data set had 180 individuals

\begin{tabular}{|lcrrcc|}
\hline & df & MS & \multicolumn{1}{c|}{$F$} & $\mathrm{p}$ & $\mathrm{r}^{2}$ \\
\hline $\mathrm{Mg}: \mathrm{Ca}$ & 8 & 0.145 & 7.63 & $<0.0001$ & 23.3 \\
$\mathrm{Mn}: \mathrm{Ca}$ & 8 & 0.196 & 4.21 & $<0.0001$ & 12.7 \\
$\mathrm{Sr}: \mathrm{Ca}$ & 8 & 0.000 & 60.4 & $<0.0001$ & 60.4 \\
$\mathrm{Ba}: \mathrm{Ca}$ & 8 & 0.000 & 55.1 & $<0.0001$ & 70.8 \\
$87: 86 \mathrm{Sr}$ & 8 & 0.000 & 78.2 & $<0.0001$ & 77.6 \\
$\delta^{13} \mathrm{C}$ & 8 & 338.5 & 381.5 & $<0.0001$ & 94.5 \\
$\delta^{18} \mathrm{O}$ & 8 & 115.9 & 28.4 & $<0.0001$ & 55.2 \\
\hline
\end{tabular}

of locations in comparison to pooled remaining samples (Table S1 in the supplement). Similarities were most apparent in $\mathrm{Sr}: \mathrm{Ca}, \delta^{18} \mathrm{O}$, and $\delta^{13} \mathrm{C}$ for samples from the head of St. Mary's Bay. Several of the elements (e.g. Ba:Ca and Sr:Ca) were highly correlated (Pearson's correlation), and these elements were significantly associated with all isotope ratios (Table 3, Fig. S1 in the supplement). The nature of the correlations varied depending on the element or isotope considered (Table 3). Generally Mg: $\mathrm{Ca}, \mathrm{Sr}: \mathrm{Ca}$, and the iso-
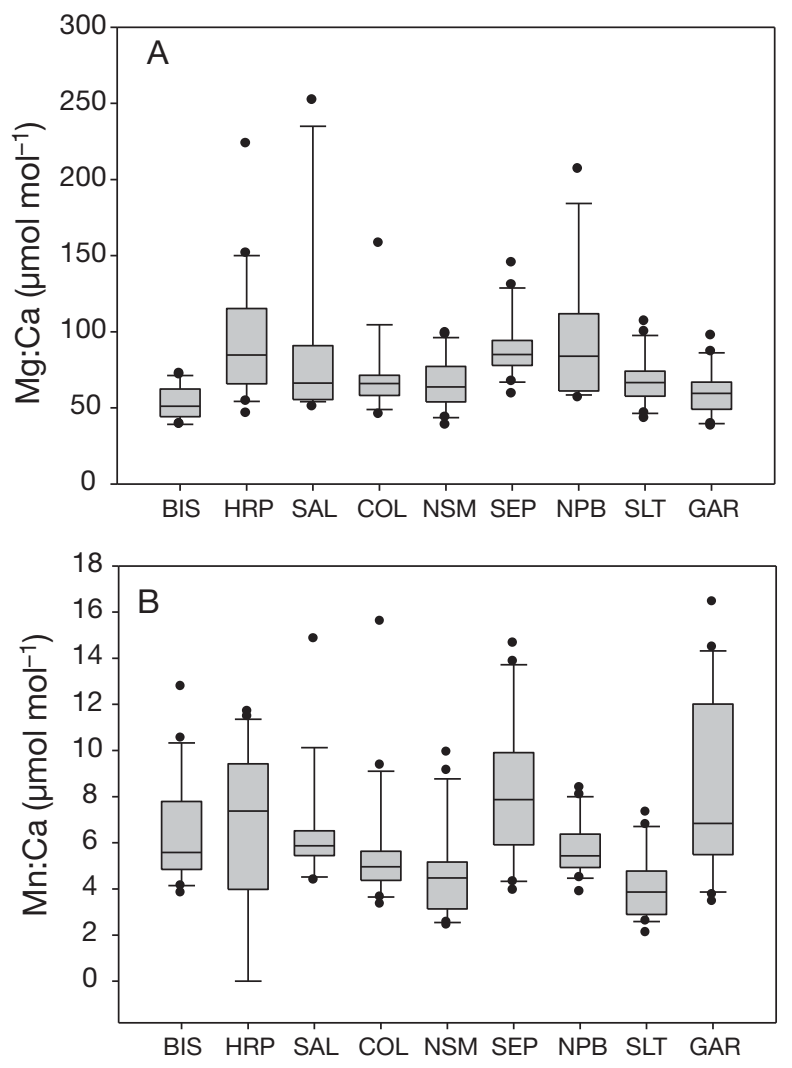

topes examined were all positively associated with each other, and negatively correlated with $\mathrm{Ba}$ :Ca and Mn:Ca. Multivariate analysis (MANOVA) showed significant variation at multiple spatial scales, where sample location (Pillai's Trace $=2.87, F=14.3, \mathrm{p}<0.001$ ), pooled $(2,3,5,7)$ sample locations (Pillai's Trace $=2.54$, $F=24.3, \mathrm{p}<0.001$ ), and bay (Pillai's Trace $=1.14, F=$ $31.8, \mathrm{p}<0.001$ ) all explained significant components of the variance.

\section{Classification success}

The QDFA of the elemental data produced correct assignments ranging from 26 to $85 \%$ per location, averaging $63 \%$. Overall Garnish, Holyrood Pond, and Salt Pond were most distinct using the QDFA (Fig. S2 in the supplement). Correct assignment was highest for Garnish River (85\%, Table 4) and lowest for North Harbour (Placentia Bay) and the samples from the head of St. Mary's Bay (Table 4). The QDFA of the isotopic data correctly assigned individuals from 60 to $100 \%$ per location, with an average of $87 \%$. Again, correct assignment was highest for Garnish River
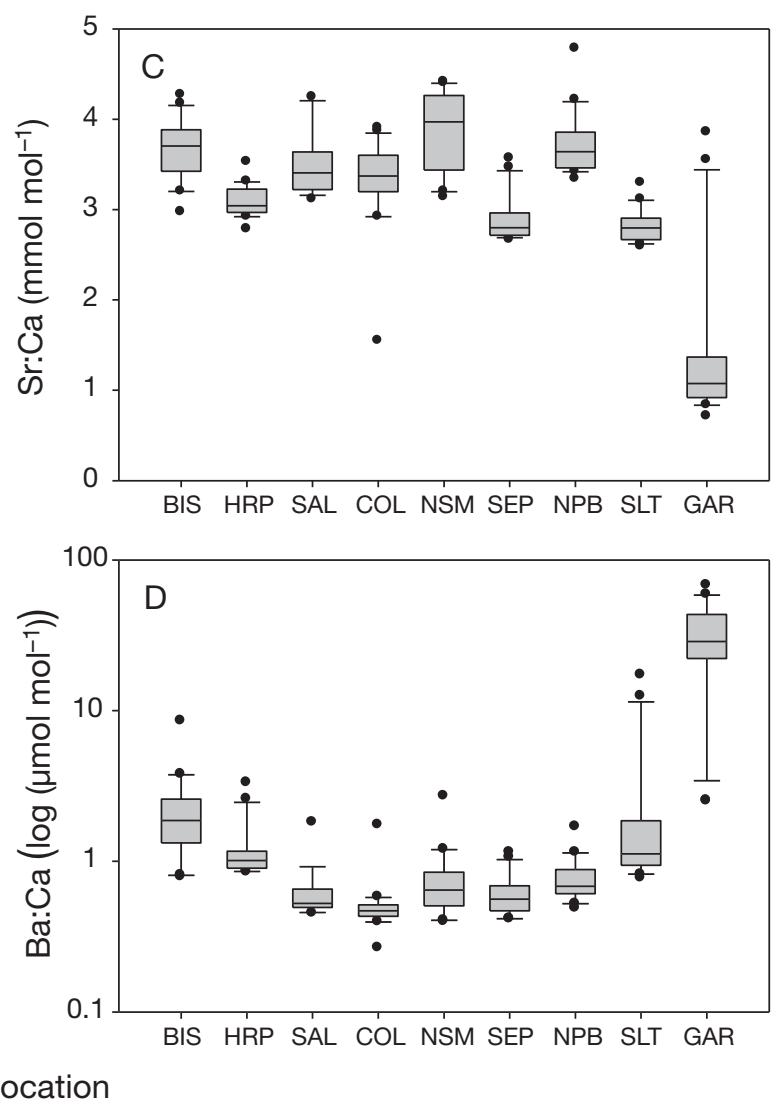

Fig. 2. Four otolith element ratios in rainbow smelt otoliths by sampling location. (A) Mg:Ca, (B) Mn:Ca, (C) Sr:Ca, (D) Ba:Ca. Horizontal line within box: median value; top and bottom edges of box: 25th and 75th percentiles; whiskers: 5th and 95th percentiles; filled circles: outliers beyond 95th percentile. Location codes in Table 1 
(100\%, Table 4). With all elemental and isotope ratios included, average correct assignment was $83 \%$, ranging from 63 to $100 \%$, with Garnish assigning 100\% correctly (Table 4, Fig. 4, Fig. S3 in the supplement). The decline in assignment success with both types of data in comparison to the isotopes alone is largely associated with an average $10 \%$ drop in successful assignment at fine $(<20 \mathrm{~km})$ spatial scales, primarily among Colinet,
Table 3. Pearson's correlation coefficient among elements and isotopes examined (above diagonal) and p-values (below diagonal). Bonferonni adjusted $\alpha=0.002$

\begin{tabular}{|lccrrrrr|}
\hline & Mg:Ca & Mn:Ca & Sr:Ca & Ba:Ca & ${ }^{87: 86} \mathrm{Sr}$ & $\delta^{13} \mathrm{C}$ & $\delta^{18} \mathrm{O}$ \\
\hline $\mathrm{Mg}: \mathrm{Ca}$ & & 0.077 & 0.106 & -0.155 & 0.002 & 0.107 & 0.014 \\
$\mathrm{Mn}: \mathrm{Ca}$ & 0.316 & & -0.327 & 0.181 & -0.272 & -0.255 & -0.287 \\
$\mathrm{Sr}: \mathrm{Ca}$ & 0.162 & 0.000 & & -0.762 & 0.375 & 0.710 & 0.448 \\
$\mathrm{Ba}: \mathrm{Ca}$ & 0.040 & 0.016 & 0.000 & & -0.541 & -0.741 & -0.408 \\
${ }^{87}: 86 \mathrm{Sr}$ & 0.983 & 0.000 & 0.000 & 0.000 & & 0.625 & 0.448 \\
$\delta^{13} \mathrm{C}$ & 0.159 & 0.001 & 0.000 & 0.000 & 0.000 & & 0.578 \\
$\delta^{18} \mathrm{O}$ & 0.852 & 0.000 & 0.000 & 0.000 & 0.000 & 0.000 & \\
& & & & & & & \\
\hline
\end{tabular}
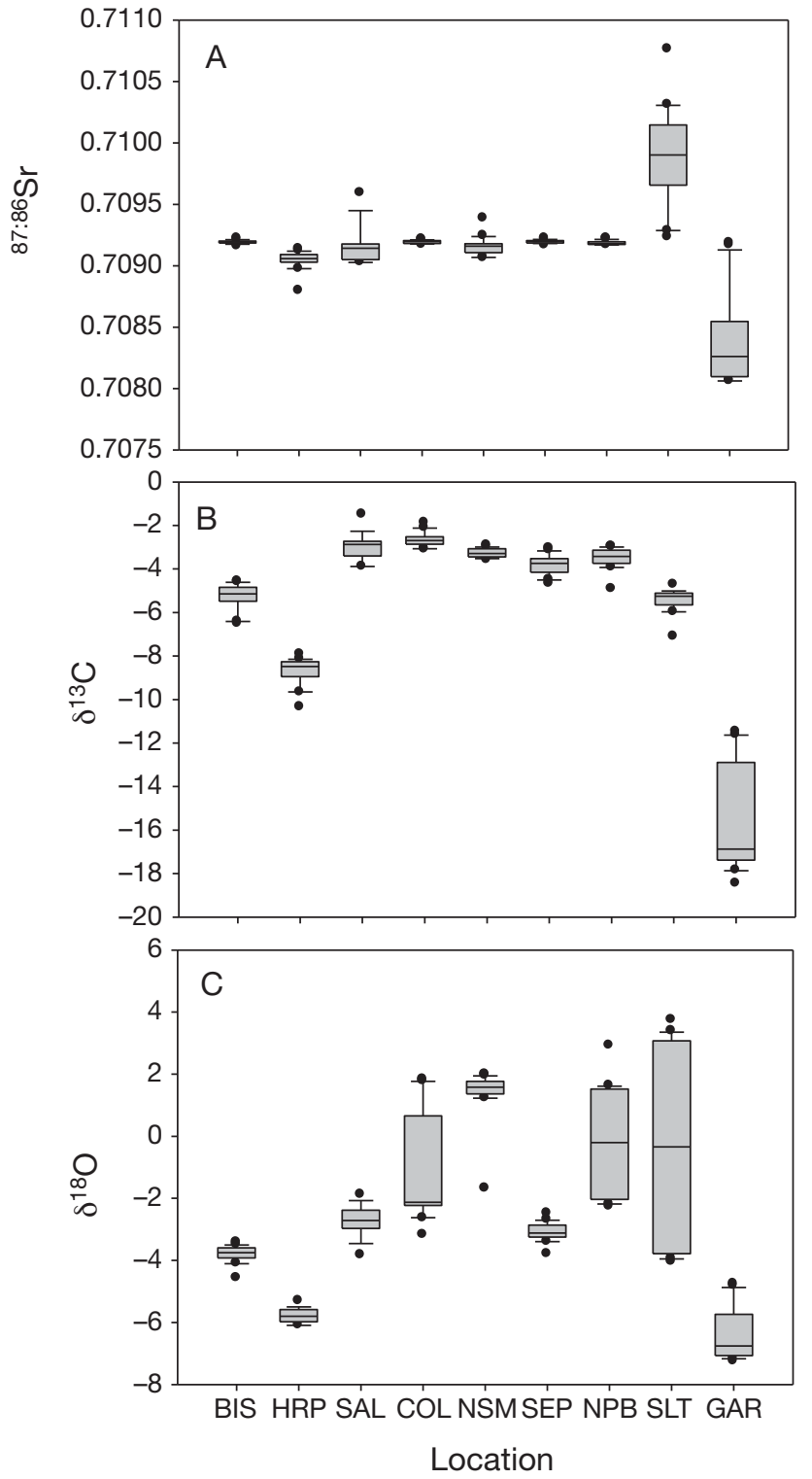

Fig. 3. Three otolith isotope ratios by sampling location. (A) ${ }^{87: 86} \mathrm{Sr},(\mathrm{B}) \delta^{18} \mathrm{O},(\mathrm{C}) \delta^{13} \mathrm{C}$. Horizontal line within box: median value; top and bottom edges of box: 25th and 75th percentiles; whiskers: 5th and 95th percentiles; filled circles: outliers beyond 95th percentile. Location codes see Table 1
Table 4. Percentage of rainbow smelt juveniles correctly assigned to sampling location using otolith composition, both elemental and stable isotope data, and a quadratic discriminant function analysis with cross-validation. For each location, highest self-assignment estimate is indicated in bold

\begin{tabular}{|llcrr|}
\hline ID & Location name & $\begin{array}{c}\text { Elemental } \\
\text { data only }\end{array}$ & $\begin{array}{r}\text { Isotope } \\
\text { only }\end{array}$ & $\begin{array}{c}\text { All } \\
\text { data }\end{array}$ \\
\hline 1 & Biscay Bay, SMB & 80 & $\mathbf{9 5}$ & 90 \\
2 & Holyrood Pond, SMB & 65 & $\mathbf{9 5}$ & $\mathbf{9 5}$ \\
3 & Salmonier, SMB & 78 & $\mathbf{8 4}$ & 78 \\
4 & Colinet, SMB & 26 & $\mathbf{8 0}$ & 69 \\
5 & North Harbour, SMB & 50 & $\mathbf{8 5}$ & 70 \\
6 & Southeast Placentia, PB & 80 & $\mathbf{9 0}$ & 85 \\
7 & North Harbour, PB & 37 & 60 & $\mathbf{6 3}$ \\
8 & Salt Pond, PB & 65 & $\mathbf{9 5}$ & $\mathbf{9 5}$ \\
9 & Garnish, FB & 85 & $\mathbf{1 0 0}$ & $\mathbf{1 0 0}$ \\
& Average & $\mathbf{6 3}$ & $\mathbf{8 7}$ & $\mathbf{8 3}$ \\
\hline
\end{tabular}

Salmonier, and North Harbour (St. Mary's Bay; Table 4, Fig. 4). Locations characterized by limited exchange (e.g. partial sand bars versus open estuaries) differed significantly from those open to the coast for $\mathrm{Mn}: \mathrm{Ca}$, Sr:Ca, Ba:Ca, $\delta^{13} \mathrm{C}$, and $\delta^{18} \mathrm{O}$ (Fig. 5). Habitat type also impacted assignment success, in that sites with partially restricted marine access (e.g. blocked by sand bars) assigned correctly at significantly higher rates than open locations (ANOVA, $F=33.72 ; \mathrm{p}<0.001 ; \mathrm{r}^{2}=$ 80.36). Pooling all open estuaries and all closed estuaries, a QDFA correctly assigned samples to habitat type with a total $84 \%$ accuracy, corresponding to $77 \%$ of closed estuary individuals and $91 \%$ of open estuary individuals, supporting significant differences among habitat type and greater homogeneity among individuals from open estuaries.

\section{DISCUSSION}

The persistence and stability of populations depends largely on patterns of connectivity and dispersal (Hastings \& Botsford 2006, Botsford et al. 2009, Campbell Grant et al. 2010), yet for most marine and estuarine or- 

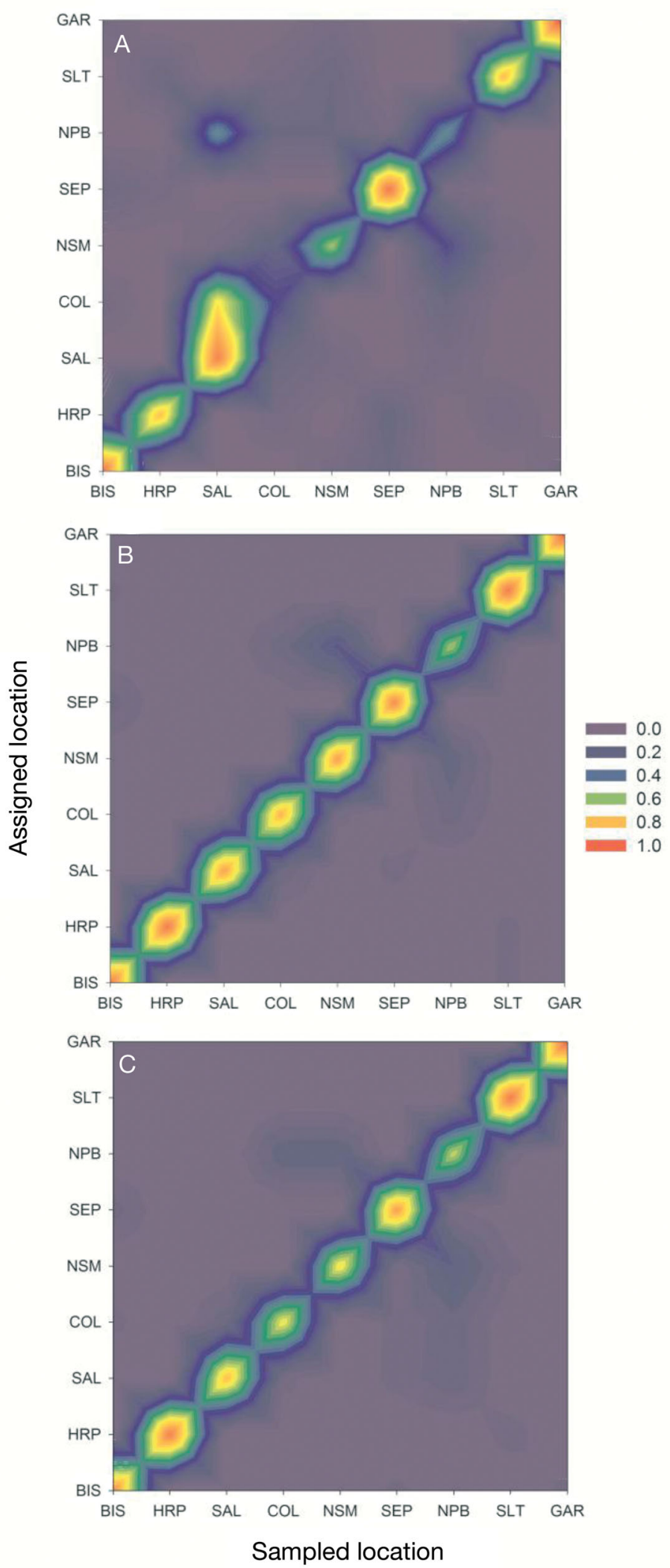

Fig. 4. Degree (proportion) of assignment success for juvenile smelt based on (A) elemental composition, (B) isotopic composition, and $(\mathrm{C})$ combined data ganisms the scales of dispersal remain unknown (Bradbury et al. 2008a). We evaluated the use of otolith geochemistry in coastal Newfoundland as a natural tag in juvenile rainbow smelt using a suite of elements and isotope ratios. We observed consistent spatial variation among individuals from estuaries and significant associations among several of the elements and isotopes examined, consistent with a common response to estuarine differences. Spatial variation in otolith composition permitted successful classification of individuals to estuary of capture with high $(\sim 87 \%)$ accuracy. Assignment accuracy was highest using isotope ratios and for sites with obstructions preventing open access to the sea, both of which relate to consistent stable differences in salinity among regions. These observations support a growing literature documenting significant spatial variation in otolith geochemistry of estuarine fishes (e.g. Thorrold et al. 2001, Fodrie \& Levin 2008) and the potential for further insight into marine connectivity based on otolith composition. Geochemical signatures identified here, indicative of natal or nursery location, allow currently unparalleled resolution of dispersal patterns later in life and support further use in other marine species, particularly at fine spatial scales where movement among locations is common (e.g. Campana et al. 1999, Thorrold et al. 2001, Elsdon et al. 2008).

Numerous studies report spatial variation in otolith geochemistry in marine, estuarine, and anadromous species (Campana \& Thorrold 2001, Gillanders et al. 2001, Elsdon et al. 2008). We observed significant spatial variation in otolith composition at large $(100 \mathrm{~km})$ and fine (5 to $10 \mathrm{~km}$ ) spatial scales in rainbow smelt. Similar observations of fine-scale geochemical variation have been reported for other species and locations (e.g. Thorrold et al. 1998, Gillanders \& Kingsford 2000, Clarke et al. 2009, Tanner et al. 2011) and, as frequently noted, much of the small-scale discrimination among the samples here is driven by variability in isotope ratios. Isotope ratios in particular accurately assigned the 3 locations at the head of St. Mary's Bay over fine $(<20$ $\mathrm{km}$ ) spatial scales, where the $51 \%$ accurate assignment with elemental data increased to $83 \%$ for the isotope data. Of the geochemical variables among sites, we found that $\delta^{13} \mathrm{C}$ values differed most. The proportion of metabolic carbon incorporated into otoliths has been shown to vary with diet, metabolic rate, and ontogeny (Solomon et al. 2006, Elsdon et al. 2010). Smelt across the study area varied widely in growth rate, age at maturity, and trophic strategy (e.g. planktivorous or piscivorous; Bradbury et al. 2008b, 2009b). A large variation in $\delta^{13} \mathrm{C}$ is therefore perhaps not surprising.

In addition to dietary sources, spatial variation in salinity may explain a significant component of variation in the chemicals examined. Salinity differences may contribute to geochemical composition, and $\delta^{13} \mathrm{C}$ 


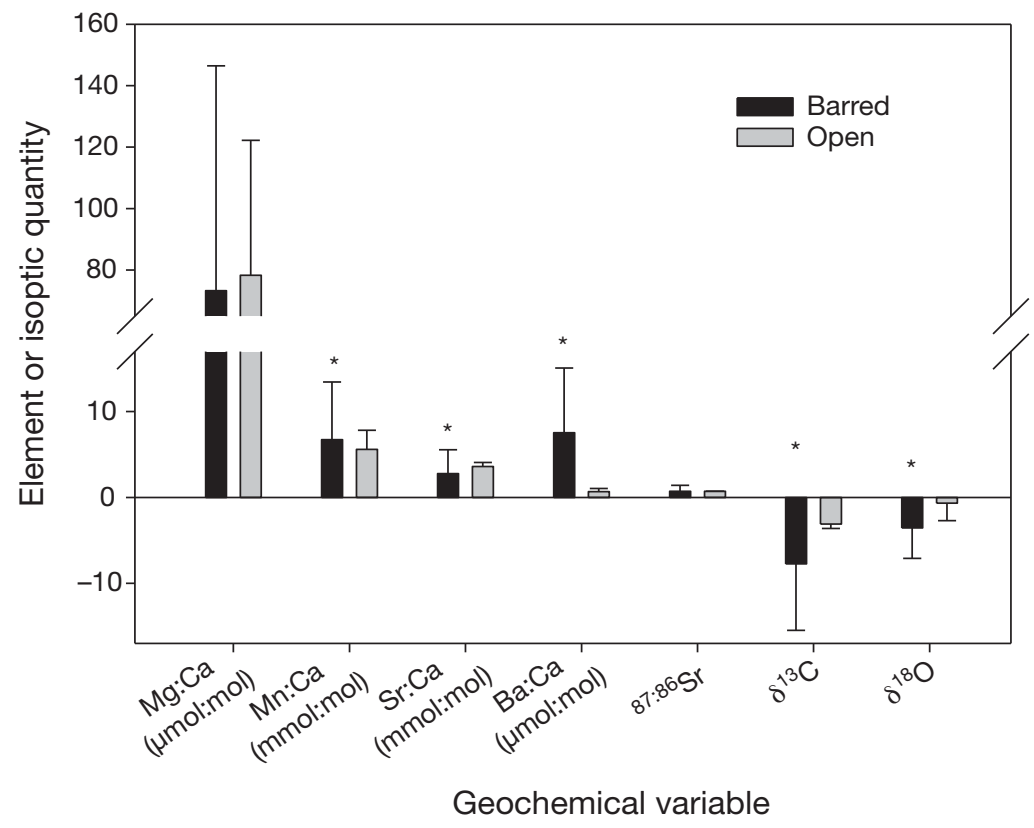

Fig. 5. Elements and isotopes (average \pm SD) measured in rainbow smelt otoliths from both barred and open estuaries. * significant differences, $\mathrm{p}<0.001$

values in otoliths have also been found to correlate with salinity (Kerr et al. 2007), as have the remaining 4 geochemical signatures (Sr:Ca, Ba:Ca, ${ }^{87: 86} \mathrm{Sr}$, and $\delta^{18} \mathrm{O}$ ), which also vary spatially (Thorrold et al. 1997 , Elsdon et al. 2008). The significant correlations among these elements and isotopes support the hypothesis of a common environmental influence such as ambient salinity. The nature of the correlations observed likely reflects differences or similarities in the relative availability of elements in marine and freshwater environments (e.g. Elsdon et al. 2008). The link with estuarine structure and salinity is further supported by the clear distinction in otolith composition between barred and open estuaries observed in multiple elemental signatures. Unfortunately, we lack an estimate of long-term trends in salinity at each of the sites sampled. It also seems reasonable to hypothesize that estuarine structure (i.e. whether open or closed) could influence early-life dispersal (e.g. Bradbury et al. 2006) or adult movements, linking the presence of discrete otolith tags with limited connectivity. Although it remains untested, this hypothesis may be explored using tags presented here as well as molecular genetic approaches (e.g. Bradbury et al. 2008c).

The geochemical signatures in individuals from Garnish River were most distinct, deviating significantly from the other samples for 5 of the 7 chemicals examined. This divergent geochemical signature may be associated with an unusual migratory behavior in this population. Contrary to the spring spawning migrations to the head of the tide characteristic of smelt, Gar- nish River smelt migrate upstream in the fall and overwinter in a headwater lake, after which they spawn in the lake inflows before migrating back to the estuary in the spring (I. R. Bradbury et al. unpubl. data). Larvae are present in the estuary by early fall, indicating downstream movement sometime in spring and summer. This freshwater residency is likely responsible for the large divergence we observed in otolith composition. Transects of Sr:Ca and ${ }^{87: 86} \mathrm{Sr}$ across the first year of life reveal individual variation in the time of appearance in the estuary. Most individuals examined displayed consistent regions of freshwater otolith signatures (i.e. non-marine ${ }^{87: 86} \mathrm{Sr}$ values) at the core, indicative of lake residency for several weeks to months (I. R. Bradbury unpubl. data). In addition to the Garnish River population, longer freshwater exposure and greater dependence on zooplankton for food likely contributed to the unique chemical composition of otoliths in smelt from Holyrood Pond, on St. Mary's Bay (Bradbury et al. 2009a,b). This population is morphologically discrete and matures at an early age and size (Bradbury et al. 2009b).

Geochemical differences allowed correct assignment of individuals to location of capture. Assignment accuracy varied with the geochemical parameter, and increased significantly ( 20\%) with the use of the isotope data, as noted elsewhere (e.g. Clarke et al. 2009). We observed the highest rates of accurate assignment for isotope values alone, which increased assignment success by $\sim 10 \%$ for locations near the head of St. Mary's Bay. Overall, accurate assignment averaged $87 \%$ for the isotope data alone, and all estimates of accurate assignment exceeded $80 \%$. Similar estimates of accurate assignment in estuarine and anadromous fish have been reported in weakfish $190 \%$; Thorrold et al. 1998) and in American shad (91\%; Walther et al. 2008). Exceedingly high rates of accurate assignment were primarily associated with some of the barred estuaries such as Garnish River (100\% accuracy), Salt Pond (95\% accuracy), and Holyrood Pond (95\% accuracy). North Harbour (Placentia Bay) displayed the lowest rates of correct assignments despite its clear geographic isolation. The reason for this remains unclear and will require further examination.

Our observations of distinct tags may be used to provide estimates of movement across the life history of rainbow smelt in subsequent studies. Previous work indicates that dispersal potential in smelt may vary dramatically with ontogeny. Upon hatching, the trans- 
port of larvae to the estuary depends heavily on local hydrography, although the role of vertical migration behavior may increase with development (Bradbury et al. 2006). Larval and juvenile stages largely associate with low-salinity water in the upper reaches of estuaries, although some reports offer evidence of dispersal between neighboring estuaries (Bradbury et al. 2008b,c). For adult stages, McKenzie (1964) and Murawski et al. (1980) both observed straying between spawning locations in a single estuary. Similarly, Rupp (1968) reported mixing between spawning locations within a freshwater system over 6 to $7 \mathrm{~km}$. In contrast, Magnin \& Beaulieu (1965) reported average displacement rates for the St. Lawrence estuary of $150 \mathrm{~km}$, with some individuals moving as far as $300 \mathrm{~km}$, and a daily displacement of $42 \mathrm{~km} \mathrm{~d}^{-1}$ in the St. Lawrence estuary. Interestingly, evidence of straying over fine spatial scales (larvae and adults) does not seem to influence population divergence, at least in one instance. Bradbury et al. (2008b,c, 2009a,b) report evidence of larvae and adult straying among populations that display evidence of genetic isolation using microsatellite loci. The persistence of isolation in the face of dispersal may reflect local adaptation and strong selection against straying (Bradbury et al. 2008c). The ability to identify dispersed individuals will allow the examination of the strength of selection against migrating individuals and quantification of the contribution of various structuring forces.

\section{SUMMARY}

We observed significant spatial variation in otolith elemental and isotopic composition, which permitted the accurate assignment of individuals to location of origin. Such natural tags will permit the characterization of dispersal kernels in smelt across the entire life history, and help disentangle the roles of dispersal, survival, and adaptation on population structure. At present, the lack of understanding of the scale of dispersal and connectivity in most marine and estuarine species presents a real obstacle for conservation and management efforts. The use of otolith geochemistry as a geo-referenced tag represents a significant advance in tracking the movements of fish in coastal and oceanic habitats, and in defining spatial habitat usage across the entire life history.

Acknowledgements. The authors thank the many individuals who assisted with field collections, as well as those who assisted with sample preparation and processing (M. Coulson, J. Fitzgerald, J. Harris, T. Lum). Research funding and support was provided by a National Sciences Engineering Research Council (NSERC) Strategic Grant on Connectivity in Marine Fish. I.R.B. was also supported by a NSERC postdoctoral fellowship.

\section{LITERATURE CITED}

Almany G, Connolly SR, Heath DD, Hogan JD and others (2009) Connectivity, biodiversity conservation, and the design of marine reserve networks for coral reefs. Coral Reefs 28:339-351

> Barnett-Johnson R, Ramos FC, Grimes CB, MacFarlane RB (2005) Validation of Sr isotopes in otoliths by laser ablation multicollector inductively coupled plasma mass spectrometry (LA-MC-ICPMS): opening avenues in fisheries science applications. Can J Fish Aquat Sci 62: 2425-2430

Botsford LW, Coffroth MA, Jones GP, Paris CB and others (2009) Connectivity and resilience of coral reef metapopulations in marine protected areas: matching empirical efforts to predictive needs. Coral Reefs 28:327-337

Bradbury IR, Bentzen P (2007) Non-linear genetic isolation by distance: implications for dispersal estimation in anadromous and marine fish populations. Mar Ecol Prog Ser 340:245-257

Bradbury IR, Snelgrove PVR (2001) Contrasting larval transport in demersal fish and benthic invertebrates: the roles of behaviour and advective processes in determining spatial pattern. Can J Fish Aquat Sci 58:811-823

> Bradbury IR, Campana SE, Bentzen P, Snelgrove PVR (2004) Synchronized hatch and its ecological significance in rainbow smelt Osmerus mordax in St. Mary's Bay, Newfoundland. Limnol Oceanogr 49:2310-2315

Bradbury IR, Gardiner K, Snelgrove PVR, Campana SE, Bentzen P, Guan L (2006) Larval transport, vertical distribution, and localized recruitment in anadromous rainbow smelt (Osmerus mordax). Can J Fish Aquat Sci 63: 2822-2836

> Bradbury IR, Laurel B, Snelgrove PVR, Bentzen P, Campana SE (2008a) Global patterns in marine dispersal estimates: the influence of geography, taxonomic category and life history. Proc Biol Sci 275:1803-1810

> Bradbury IR, Campana SE, Bentzen P (2008b) Otolith elemental composition and adult tagging reveal spawning site fidelity and estuarine dependency in rainbow smelt. Mar Ecol Prog Ser 368:255-268

Bradbury IR, Campana SE, Bentzen P (2008c) Estimating contemporary early life-history dispersal in an estuarine fish: integrating molecular and otolith elemental approaches. Mol Ecol 17:1438-1450

Bradbury IR, Snelgrove PVR, Bentzen P, de Young B, Gregory RS, Morris CJ (2009a) Structural and functional connectivity of marine fishes within a semi-enclosed Newfoundland fjord. J Fish Biol 75:1393-1409

Bradbury IR, Coulson MW, Campana SE, Baggs E, Bentzen P (2009b). Postglacial recolonization and the loss of anadromy in rainbow smelt from coastal Newfoundland. In: Haro A et al. (eds) Challenges for diadromous fishes in a dynamic global environment. American Fisheries Society, Bethesda, MD, p 79-96

Cadrin SX, Friedland KD, Waldman JR (2005) Stock identification methods: applications in fishery science. Elsevier Academic Press, Amsterdam.

> Campana SE, Thorrold SR (2001) Otoliths, increments, and elements: Keys to a comprehensive understanding of fish populations? Can J Fish Aquat Sci 58:30-38

Campana SE, Chouinard GA, Hanson JM, Frechet A (1999) Mixing and migration of overwintering Atlantic cod (Gadus morhus) stocks near the mouth of the Gulf of St. Lawrence. Can J Fish Aquat Sci 56:1873-1881

> Campbell Grant EH, Nichols JD, Lowe W, Fagan WF (2010) Use of multiple dispersal pathways facilitates amphibian 
persistence in stream networks. Proc Natl Acad Sci USA 107:6936-6940

Clarke LM, Walther BD, Munch SB, Thorrold SR, Conover DO (2009) Chemical signatures in the otoliths of a coastal marine fish, Menidia menidia, from the northeastern United States: spatial and temporal differences. Mar Ecol Prog Ser 384:261-271

DiBacco C, Levin LA, Sala E (2006) Connectivity in marine ecosystems: the importance of larval and spore dispersal. In: Crooks KR, Sanjayan M (eds) Connectivity conservation. Cambridge University Press, Cambridge. p 184-212

Elsdon TS, Ayvazian S, McMahon KW, Thorrold SR (2010) Experimental evaluation of stable isotope fractionation in fish muscle and otoliths. Mar Ecol Prog Ser 408:195-205

Elsdon TS, Wells BK, Campana SE, Gillanders BM and others (2008) Otolith chemistry to describe movements and lifehistory parameters of fishes: hypotheses, assumptions, limitations and inferences. Oceanogr Mar Biol Annu Rev 46:297-330

Fodrie FJ, Herzka SZ (2008) Tracking juvenile fish movement and nursery contribution within arid coastal embayments via otolith microchemistry. Mar Ecol Prog Ser 361:253-265

Fodrie FJ, Levin LA (2008) Linking juvenile habitat utilization to population dynamics of California halibut. Limnol Oceanogr 53:799-812

Gillanders BM, Kingsford MJ (2000) Elemental fingerprints of otoliths of fish may distinguish estuarine 'nursery' habitats. Mar Ecol Prog Ser 201:273-286

Gillanders BM, Sanchez-Jerez P, Bayle-Sempere JT, RamosEspla A (2001) Trace elements in otoliths of the twobanded bream from a coastal region in the south-west Mediterranean: Are there differences among locations? J Fish Biol 59:350-363

> Hastings A, Botsford LW (2006) Persistence of spatial populations depends on returning home. Proc Natl Acad Sci USA 103:6067-6072

> Hedges KJ, Ludsin SA, Fryer BJ (2004) Effects of ethanol preservation on otolith microchemistry. J Fish Biol 64: 923-937

> Jackson MG, Hart SR (2006) Strontium isotopes in melt inclusions from Samoan basalts: implications for heterogeneity in the Samoan plume. Earth Planet Sci Lett 245:260-277

Jones GP, Planes S, Thorrold S (2005) Coral reef fish larvae settle close to home. Curr Biol 15:1314-1318

Kerr LA, Secor DH, Kraus TR (2007) Stable isotope $\left(\delta^{13} \mathrm{C}\right.$ and $\delta^{18} \mathrm{O}$ ) and $\mathrm{Sr} / \mathrm{Ca}$ composition of otoliths as proxies for environmental salinity experienced by an estuarine fish. Mar Ecol Prog Ser 349:245-253

Laprise R, Dodson JJ (1989) Ontogeny and importance of tidal vertical migrations in the retention of larval smelt Osmerus mordax in a well-mixed estuary. Mar Ecol Prog Ser 55:101-111

Levin LA (2006) Recent progress in understanding larval dispersal: new directions and digressions. Integr Comp Biol 46:282-297

Magnin E, Beaulieu G (1965) Quelques données sur la biologie de l'Éperlan Osmerus eperlanus mordax (Mitchill) du Saint-Laurent. Nat Can (Que) 92:81-105

McKenzie RA (1964) Smelt life history and fishery in the Miramichi River, New Brunswick, Bull 144. Fisheries Research Board of Canada, Ottawa
Methven DA, Schneider DC, Ings DW (1998) Results of the 1997 Fleming survey of demersal juvenile cod in the coastal zone of eastern Newfoundland. Res Doc 1998/077. Canadian Science Advisory Secretariat, Ottawa

Murawski SA, Clayton GR, Reed RJ, Cole CF (1980) Movements of spawning rainbow smelt, Osmerus mordax, in a Massachusetts estuary. Estuaries 3:308-314

Nellbring S (1989) The ecology of smelts (genus Osmerus): a literature review. Nord J Freshw Res 65:116-145

Ouellet P, Dodson JJ (1985) Dispersion and retention of anadromous rainbow smelt (Osmerus mordax) larvae in the middle estuary of the St. Lawrence River. Can J Fish Aquat Sci 42:332-341

Pineda J, Hare JA, Sponaugle S (2007) Larval transport and dispersal in the coastal ocean and consequences for population connectivity. Oceanogr 20:22-39

Rupp RS (1968) Life history and ecology of the smelt (Osmerus mordax) in the inland waters of Maine. Fed Aid to Fisheries Proj F-10-R. Maine Dept of Inland Fish and Game, Augusta, ME

Saenz-Agudelo P, Jones GP, Thorrold SR, Planes S (2009) Estimating connectivity in marine populations: an empirical evaluation of assignment tests and parentage analysis under different gene flow scenarios. Mol Ecol 18: $1765-1776$

Sale PF, Cowen RK, Danilowicz BS, Jones GP and others (2005) Critical science gaps impede use of no-take fishery reserves. Trends Ecol Evol 20:74-80

Solomon CT, Weber PK, Cech JJ, Ingram BL and others (2006) Experimental determination of the sources of otolith carbon and associated isotopic fractionation. Can J Fish Aquat Sci 63:79-89

Sturgeon RE, Willie SN, Yang L, Greenberg R and others (2005) Certification of a fish otolith reference material in support of quality assurance for trace element analysis. J Anal At Spectrom 20:1067-1071

Tanner SE, Vasconcelos RP, Reis-Santos P, Cabral HN, Thorrold SR (2011) Spatial and ontogenetic variability in the chemical composition of juvenile common sole (Solea solea) otoliths. Estuar Coast Shelf Sci 91:150-157

Thorrold SR, Swearer SE (2009). Otolith chemistry. In: Green BS, Mapstone BD, Carlos G, Begg GA (eds) Tropical fish otoliths: information for assessment, management and ecology. Springer, Dordrecht, p 249-295

- Thorrold SR, Campana SE, Jones CM, Swart PK (1997) Factors determining $\delta^{13} \mathrm{C}$ and $\delta^{18} \mathrm{O}$ fractionation in aragonitic otoliths of marine fish. Geochim Cosmochim Acta 61: 2909-2919

Thorrold SR, Jones CM, Campana SE, McLaren JW, Lam JWH (1998) Trace element signatures in otoliths record natal river of juvenile American shad (Alosa sapidissima). Limnol Oceanogr 43:1826-1835

Thorrold SR, Latkoczy C, Swart PK, Jones CM (2001) Natal homing in a marine fish metapopulation. Science 291: 297-299

Walther BD, Thorrold SR, Olney JE (2008) Geochemical signatures in otoliths record natal origins of American shad. Trans Am Fish Soc 137:57-69

Yoshinaga J, Nakama A, Morita M, Edmonds JS (2000) Fish otolith reference material for quality assurance of chemical analyses. Mar Chem 69:91-97
Editorial responsibility: Stylianos Somarakis, Heraklion, Greece
Submitted: December 6, 2010; Accepted: April 26, 2011

Proofs received from author(s): June 27, 2011 